\title{
EDITORIAL
}

\section{Vinte anos da Revista Pedagógica: um periódico científico com compromisso social, qualidade acadêmica e político- pedagógica}

\author{
VEINTE AÑOS DE LA REVISTA PEDAGÓGICA: UN PERIÓDICO CIENTÍFICO CON \\ COMPROMISO SOCIAL, CALIDAD ACADÉMICA Y POLÍTICO-PEDAGÓGICA
}

TWENTY YEARS OF PEDAGOGICAL JOURNAL: A SCIENTIFIC JOURNAL WITH SOCIAL ENGAGEMENT, ACADEMIC AND POLITICAL-PEDAGOGICAL QUALITY

Cláudia Battestin

battestin@unochapeco.edu.br

A Revista Pedagógica, nesse seu primeiro volume do ano de 2018, comemora vinte anos. É muita história para recordar, desde o ano de 1998 na sua criação pelo curso de Pedagogia da Unochapecó, a Revista passou por várias modificações, atualizações e percalços, mas nada disso impediu que importantes estudos e investigações seguissem sendo publicadas. O mestrado em Educação assume no ano de 2013 de forma coletiva e desafiadora, a história e trajetória da Revista Pedagógica. Seguimos com o intuito de preservar, valorizar e contribuir com o conhecimento local, regional, nacional e internacional através das publicações quadrimestrais. Muitos foram os homens e mulheres que se dedicaram e se comprometeram na divulgação e produção científica sobre a escola, universidade e todas as outras nuances do processo educativo que estão publicados em centenas de artigos dos mais diversos lugares e de diferentes espaços pedagógicos. Muito nos alegra em poder comemorar junto com os leitores e leitoras essa data importante e, não teríamos espaço o suficiente para rememorar todas as pessoas envolvidas neste trabalho nos últimos 20 anos da Revista, neste, inclui-se os editores e editoras, os avaliadores e avaliadoras, os autores e autoras, bolsistas, equipe técnica do suporte entre outros que sempre se dispuseram em contribuir e colaborar com a efetivação e publicação de cada edição da Revista Pedagógica. As edições destes últimos vinte anos, sempre buscaram relacionar temáticas com a realidade da educação e do cenário político nacional. Neste âmago, durante o ano de 2018, vamos relembrar e trazer presente algumas memórias da revista em cada edição. Também, destacamos que o selo comemorativo aos 20 anos da Revista, será marca de homenagem nas três edições do ano.

A Revista Pedagógica, nesse seu primeiro volume (43) do ano 2018, apresenta através da capa o desenho da mulher Mariele Franco, negra, vereadora e lutadora popular, que foi brutalmente assassinada 
juntamente com Anderson Gomes, no estado do Rio de Janeiro no dia 14 de março de 2018, provocando comoção e indignação no Brasil e mundo. A morte de Mariele representa a tentativa de silenciamento de todas as vozes contra as intervenções do estado autoritário que acredita que o enfrentamento das questões sociais se faz pela via da violência , entre tantas outras questões relativas ao atual cenário nacional de fragilidade jurídica, política e de direitos.

Nesta primeira edição foram publicados 10 artigos de diferentes universidades, estados e países. $\mathrm{O}$ artigo intitulado La comunidad de diálogo y la construcción conjunta del pensamiento filosófico, resulta da escrita de Omer Buatu Batubenge, professor africano, trabalhando atualmente na Universidade de Colima, México. A proposta investigativa busca apresentar o desapego da sociedade global diante das habilidades que apresentam a filosofia a fim de analisar as vantagens da comunidade do diálogo como estratégiadidática no que fazer filosófico.

A escrita de Andrea Coelho Lastória, José Faustino Santos e Rafael Cardoso Mello da USP e UNESP com o título Considerações sobre os retrocessos nas políticas educacionais brasileiras durante o Governo do presidente Michel Temer, O texto veicula informações sobre a Avaliação Nacional Não cognitiva (ou Socioemocional), sobre a Base Nacional Comum Curricular, a Reforma do Ensino Médio e sobre o programa Escola Sem Partido objetivando interpretar as ideias expostas no Foro 23 do Fórum Ibero Americano de Geografia, Educação e Sociedade - GEOFORO, mostrando o atual retrocesso das políticaspúblicas brasileiras.

A autora Iára Kamphorst e André Paulo Castanha da Unioeste e Colégio estadual José de Anchieta, apresentam através da escrita Educação e formação humana: impasses entre métodos, ideologias e doutrinaçãoprocura identificar alguns momentos em que a relação métodos, ideologias ou "doutrinação" foram ocupando espaços na esfera pedagógica, e atuando diretamente na formação humana. Os embates no Brasil estão alicerçados nas proposições de Anísio Teixeira, Paulo Freire e Saviani, passando pelas críticas feitas à educação atual pelo movimento da Escola Sem Partido, definido como "doutrinação ideológica”.

A militarização das escolas da rede estadual de goiás: a nova onda conservadora é resultado da escrita dePaula Cristina Pereira GuimarãesRodrigo de Azevedo Cruz Azevedo Cruz Lamos da UFRRJ, apresenta o recente e aligeirado processo de militarização de parte das escolas da rede estadual de ensino do Estado de Goiás. O artigo uma pesquisa acerca deste processo, que transfere para a Polícia Militar de Goiás uma parte das escolas do ensino básico, através de uma parceria entre as Secretarias Estaduais de Educação e de Segurança Pública.

Ramofly Bicalho da UFRRJ, escreve sobre Interfaces da educação do campo e movimentos sociais: 
possibilidades de formação, apresenta reflexões realizadas acerca da concepção de educação do campo, no contexto dos movimentos sociais e a formação dos educadores, mostrando que a educação do campo, enquanto práxis libertadora, é utilizada no processo de compreensão das lutas e demandas educacionais defendidas pelos movimentos sociais. Ela dialoga com os gestos, desejos, valores e luta pela terra.

O "novo" ensino médio: apontamentos sobre a retórica da reforma, juventudes e o reforço da dualidade estruturalé pesquisa de Éder da Silva Silveira e Nara Vieira Ramos da UNISC e UFRGS, que buscam através de uma problematização, apresentar críticas a respeito da reforma do Ensino Médio anunciada pelo governo Temer, expressa na Lei 13.415/2017. O texto denuncia a falácia do discurso da escolha dos jovens em relação aos itinerários formativos e o reforço da dualidade estrutural como efeito objetivo da reforma do Ensino Médio.

$O$ artigo Embates entre integração e competências no ensino médio e seus desdobramentos na reforma atual, autoria de Maria Gorete Rodrigues Cardoso e Genylton Odilon Rego da Rocha da UFPA analisa os embates entre integração e competências na política curricular para ensino médio como luta hegemônica entre projetos educacionais distintos, que não apenas se antagonizaram no cenário brasileiro nos últimos vinte anos, mas também operaram articulações que favoreceram a fixação de sentidos híbridos e ambíguos nos textos curriculares.

O fazer político dos jovens das classes populares: as ocupações estudantis paranaenses é tema discorrido por Suely Aparecida Martins da Unioeste que busca mostrar como o avanço das políticas neoliberais no Brasil e de acirramento da luta de classes, em 2016 alunos do ensino médio e superior paranaense ocuparam escolas e universidades. Este movimento ficou conhecido como Ocupa Paraná.

A investigação sobre a Qualidade de vida docente: relação entre alterações psicoemocionais e disfonias é resultado da investigação realizada por Joana Guimarães Couto e Casella e Maria Lúcia Miranda Afonso centro Universitário UNA, apresenta os impactos das alterações psicoemocionais dos educadores, no desencadeamento de disfonias e seus aspectos relacionados à qualidade de vida do portador, considerando a relação existente entre saúde vocal, estado emocional e condições de trabalho para esta categoria profissional.

Erradicação da surdez: a eugenia na escolarização dos surdos no século XIX, autoria de Morena Dolores Patriota da Silva do IFPR e Regina Maria de Souza, defendem a vinculação das ideias de Alexander Graham Bell e daquelas assumidas no Congresso Internacional de Educação para Surdos de 1880 com as teses eugênicas que, no Brasil, foram organizadas e defendidas por Renato Kehl em 1923. Os resultados indicam a influência da 
eugenia na política educacional para os surdos no século XIX, com a defesa da oralização, da coibição da expansão das escolas e das associações de surdos.

O vídeo publicado nesta edição, é da professora Vanisse Domingos, egressa do curso de licenciatura Intercultural Indígena da Unochapecó, primeiro curso ofertado na região Sul do Brasil, nesta modalidade. Vanisse é índia Kaingang, mora na Terra Indígena Toldo Chimbangue no município de Chapecó- SC, mostrando e inspirando uma trajetória marcada de transformação e conhecimento.

Youtube: https://www.youtube.com/channel/UCdDYiyX $\mathrm{KwG}_{5} \mathrm{Pn}_{1} \mathrm{CosX}_{5} 87 \mathrm{~A}$

Com esta diversidade de autores (as), universidades e contextos, fica o convite à leitura, ao contraponto, à interlocução.

Com esperança e luta, deixamos nosso abraço!

Ivo Dickmann

Cláudia Battestin

Editores desta edição

Mestrado em Educação da Unochapecó 